\title{
Harvesting Charges for Florida Citrus: Picking, Roadsiding, and Hauling, 2015/16
}

\author{
Ariel Singerman, Marina Burani-Arouca, and Stephen H. Futch ${ }^{2}$
}

\section{Introduction}

A survey of Florida citrus harvesters was conducted in July 2016 to collect data on harvesting charges during the $2015 / 16$ season. A total of seven harvesters participated in the survey and reported charges for processed fruit; four of them also reported charges for fresh fruit. The averages and range of their responses were computed to estimate the harvesting charges to Florida citrus growers during the 2015/16 season.

\section{Data}

Harvesting charges are classified into picking, roadsiding, and hauling, described as follows:

- The picking charge is for removing the fruit from the tree and filling field bins.

- The roadsiding charge is for collecting and transporting the picked fruit to the field flatbed or bulk trailer. This charge also includes the costs related to harvesting equipment (fruit pallet boxes or tubs, ladders), workers' transportation, payroll taxes, insurance, and crew supervisor's salary.

- The hauling charge is associated with transporting the fruit from the field to the packinghouse (fresh fruit) or the processing plant (juice fruit).

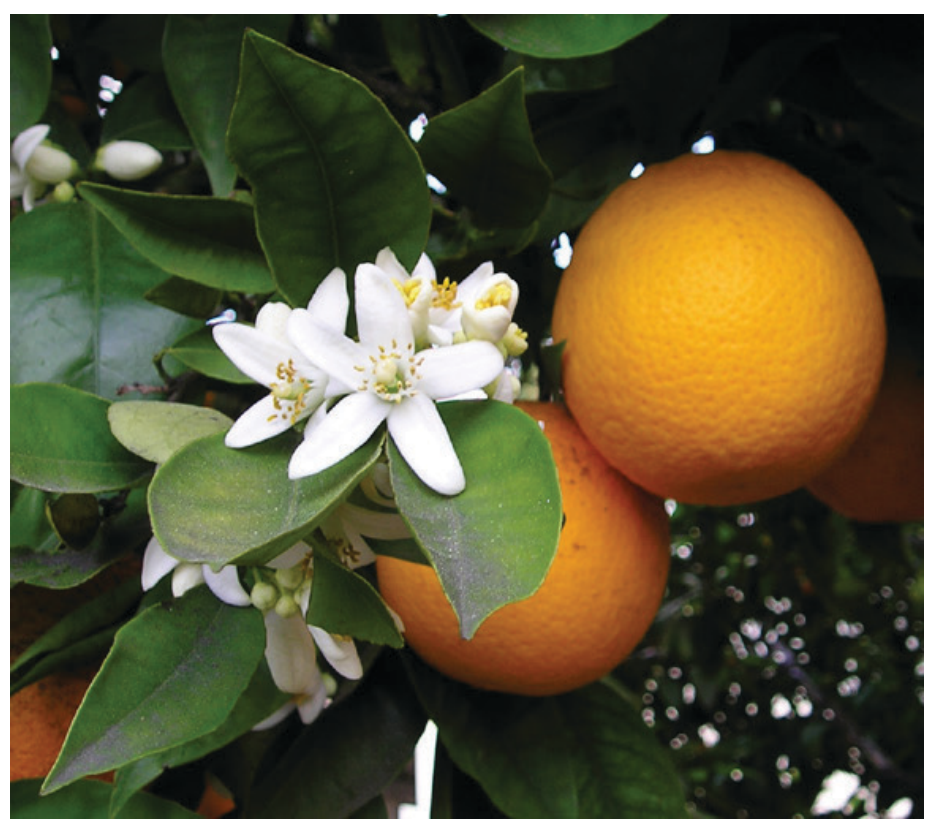

Credit: USDA

Table 1 shows the range, average, and change relative to the past season of picking, roadsiding, and hauling charges by variety and type of fruit (fresh or processed). Roadsiding for fresh fruit showed the greatest average change relative to the previous season among all three charge categories, with a $47 \%$ increase. As a comparison, the average roadsiding for processed fruit increased by $22 \%$. For processed fruit, the harvesting charge category that increased the most was picking; up 29\%, on average, compared to last season.

1. This is EDIS document FE1005, a publication of the Food and Resource Economics Department, UF/IFAS Extension. Published December 2016. Visit the EDIS website at http://edis.ifas.ufl.edu

2. Ariel Singerman, assistant professor, Food and Resource Economics Department; Marina Burani-Arouca, economics research and Extension coordinator; Stephen H. Futch, extension agent IV, Citrus; UF/IFAS Citrus Research and Education Center, Lake Alfred, FL.

The Institute of Food and Agricultural Sciences (IFAS) is an Equal Opportunity Institution authorized to provide research, educational information and other services

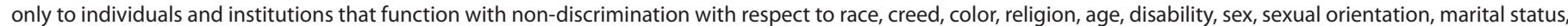

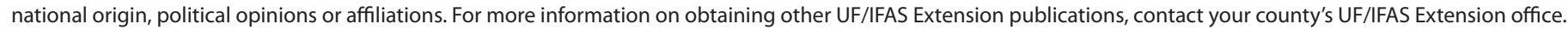
U.S. Department of Agriculture, UF/IFAS Extension Service, University of Florida, IFAS, Florida A \& M University Cooperative Extension Program, and Boards of County Commissioners Cooperating. Nick T. Place, dean for UF/IFAS Extension. 
The general increase in harvesting charges is due to lower fruit production during the 2015/16 season (caused by citrus greening, or HLB). Lower volume of fruit per tree reduces harvesting efficiency while increasing costs, especially that of picking and roadsiding. Efficency is impacted by having smaller-sized fruit, another consequence of HLB. As a result of the significant decrease in citrus production in Florida in the last few years, the industry has started a consolidation process, and harvesting companies are no exception.

A key component of harvesting is the cost of labor. Six of the companies that participated in the survey reported hiring, on average, $92 \%$ of their harvesting crews for the 2015/16 season under the H-2A temporary agricultural program (one company chose not to answer this question). The Adverse Effect Wage Rate (AEWR) (Federal Register 2014), that is, the minimum wage to be paid to foreign agricultural guest workers, was $\$ 10.19$ and $\$ 10.70$ per hour for 2015 and 2016, respectively. Comparatively, Florida’s minimum wage for domestic workers during 2015 and 2016 was $\$ 8.05$ per hour (FDOC 2015). If an employer hires only domestic workers, the state minimum wage applies. However, an $\mathrm{H}-2 \mathrm{~A}$ employer must provide domestic workers the same benefits being given to foreign workers, including the AEWR. Employers using the H-2A program also incur costs related to housing, in-bound and out-bound transportation for workers, and all recruitment and administrative costs associated with the guest worker program. All of these costs are embedded in the harvesting charges presented in this report.

The average hauling distance reported by harvesters was 90.91 miles. Table 2 shows the average total harvesting charges by variety, assuming hauling costs for 81-100 miles. An average hauling charge was applied for fresh and processed fruit at $\$ 0.72$ and $\$ 0.70$ per box, respectively.

Oranges represent the bulk of Florida citrus production, accounting for approximately $85 \%$ of the crop each year and with approximately $95 \%$ of oranges being processed for juice (USDA/NASS 2016). The average total harvesting charge across oranges for processing was $\$ 3.22$ per box. The specialty citrus varieties (temples/tangelos and tangerines) presented the highest average of total harvesting cost (picking, roadsiding, and hauling) with $\$ 5.12$ and $\$ 4.08$ per box for fresh and processed, respectively. This may be attributed to the extra labor needed to pick and handle these varieties, which are thin-skinned and peel easily, so the fruit is not damaged while being handled. Moreover, hauling costs for processed temples/tangelos and tangerines can typically be higher than those for other processed varieties. This is so because temples/tangelos and tangerines are not shipped in a fully loaded trailer because the fruit on the bottom may not stand the weight of the fruit on top.

On average, harvesting charges for the fresh fruit market are higher than for processed fruit, but it is interesting to note that as shown in Table 2 for oranges and grapefruit, charges for fresh fruit are lower than those for processed fruit. One explanation for this seemingly counterintuitive finding could be the impact of HLB. As HLB spreads across the grove, only the blocks with trees having lower HLB infection levels yield fruit that qualifies for the fresh market. Since those trees are likely to have more fruit, the cost of harvesting such blocks is lower. Contrastingly, blocks with trees having higher HLB infection levels yield lower volumes of fruit which increases the harvesting costs of such blocks.

\section{Summary}

The Florida citrus industry has started a consolidation and downsizing process as a consequence of the challenges imposed by HLB. This article summarizes the harvesting charges for citrus during the 2015/16 season and also documents the changes in harvesting costs as the impact of HLB increases across the state. On-tree prices are the basis for establishing the economic return to citrus growers. The estimates presented provide the basis for computing on-tree prices from delivered-in prices, thus allowing the computation of the change in citrus growers' economic returns as the industry adapts to remain profitable.

\section{References}

Federal Register. 2014. Labor certification process for the temporary employment of aliens in agriculture in the United States: 2015 adverse effect wage rates. Retrieved from https://www.federalregister.gov/documents/2014/12/19/2014-29746/labor-certification-processfor-the-temporary-employment-of-aliens-in-agriculturein-the-united

FDOC. 2015. Florida minimum wage history, 2000 to 2016. Retrieved from http://sitefinity.floridajobs.org/docs/ default-source/2016-minimum-wage-increases/floridaminimum-wage-history-2000-2016.pdf?status=Temp\&sfvr $\mathrm{sn}=0.5425500785086295$

Singerman, A., M. Burani-Arouca, and S.H. Futch. 2016a. Estimated average picking, roadsiding, and hauling charges for Florida citrus, 2015/16. CREC, Lake Alfred, FL. 
Singerman, A., M. Burani-Arouca, and S.H. Futch. 2016b.

Estimated average of total harvesting charges for Florida

citrus, 2015/16. CREC, Lake Alfred, FL.

United States Department of Agriculture, National Agricultural Statistics Service (USDA-NASS). 2016. Citrus forecast. Retrieved from https://www.nass.usda.gov/Statistics_by_ State/Florida/Publications/Citrus/Citrus_Forecast/2015-16/ cit0716.pdf 
Table 1. Estimated average picking, roadsiding, and hauling charges for Florida citrus, 2015/16

\begin{tabular}{|c|c|c|c|c|c|c|c|c|}
\hline & \multicolumn{4}{|c|}{ Fresh Fruit } & \multicolumn{4}{|c|}{ Processed Fruit } \\
\hline & \multicolumn{3}{|c|}{ Range } & \multirow{2}{*}{$\begin{array}{c}\text { Change } \\
\text { from } \\
2014 / 15\end{array}$} & \multicolumn{3}{|c|}{ Range } & \multirow{2}{*}{$\begin{array}{c}\text { Change } \\
\text { from } \\
2014 / 15\end{array}$} \\
\hline & $\min$. & $\max$. & Average & & $\min$. & $\max$. & Average & \\
\hline Picking Charges & \multicolumn{3}{|c|}{$\$ / b o x$} & \multicolumn{5}{|c|}{$\$ / b o x$} \\
\hline Early and Mid-season Oranges & 1.10 & 1.30 & 1.19 & $16 \%$ & 1.00 & 2.10 & 1.36 & $27 \%$ \\
\hline Valencia Oranges & 1.15 & 1.39 & 1.24 & $15 \%$ & 1.10 & 2.09 & 1.39 & $25 \%$ \\
\hline Valencia Oranges (after May 15) & 1.39 & 1.39 & 1.39 & $22 \%$ & 1.10 & 2.20 & 1.58 & $30 \%$ \\
\hline Pink/Red Grapefruit & 0.75 & 0.95 & 0.84 & $12 \%$ & 0.90 & 1.10 & 1.01 & $26 \%$ \\
\hline White/March Grapefruit & 0.80 & 0.95 & 0.88 & $17 \%$ & 0.75 & 1.60 & 1.05 & $29 \%$ \\
\hline Temples/Tangelos & 1.15 & 3.50 & 2.01 & $39 \%$ & 2.15 & 2.15 & 2.15 & $48 \%$ \\
\hline \multirow[t]{4}{*}{ Tangerines } & 1.75 & 3.25 & 2.20 & $47 \%$ & 1.75 & 1.75 & 1.75 & $17 \%$ \\
\hline & & & Average & $24 \%$ & & & Average & $29 \%$ \\
\hline & \multicolumn{3}{|c|}{ Range } & Change & \multicolumn{3}{|c|}{ Range } & Change \\
\hline & $\min$. & $\max$ & Average & $\begin{array}{c}\text { from } \\
2014 / 15\end{array}$ & $\min$. & $\max$. & Average & $\begin{array}{c}\text { from } \\
2014 / 15\end{array}$ \\
\hline Roadsiding Charges & \multicolumn{3}{|c|}{$\$ / b o x$} & \multicolumn{5}{|c|}{$\$ / b o x$} \\
\hline Early and Mid-season Oranges & 0.96 & 1.44 & 1.19 & $29 \%$ & 0.88 & 1.32 & 1.08 & $18 \%$ \\
\hline Valencia Oranges & 0.98 & 1.60 & 1.29 & $39 \%$ & 0.92 & 1.54 & 1.15 & $21 \%$ \\
\hline Valencia Oranges (after May 15) & 1.50 & 1.50 & 1.50 & $55 \%$ & 0.92 & 1.50 & 1.27 & $25 \%$ \\
\hline Pink/Red Grapefruit & 0.86 & 1.14 & 1.03 & $9 \%$ & 0.96 & 1.08 & 1.01 & $25 \%$ \\
\hline White/March Grapefruit & 0.88 & 1.14 & 1.00 & $27 \%$ & 0.85 & 1.12 & 1.01 & $18 \%$ \\
\hline Temples/Tangelos & 1.20 & 3.64 & 2.10 & $79 \%$ & 1.20 & 1.35 & 1.30 & $11 \%$ \\
\hline \multirow[t]{3}{*}{ Tangerines } & 1.50 & 3.54 & 2.27 & $91 \%$ & 1.50 & 1.70 & 1.60 & $36 \%$ \\
\hline & & & Average & $47 \%$ & & & Average & $22 \%$ \\
\hline & \multicolumn{3}{|c|}{ Average All Varieties } & $\begin{array}{c}\text { Change } \\
\text { from } \\
2014 / 15\end{array}$ & \multicolumn{3}{|c|}{ Average All Varieties } & $\begin{array}{c}\text { Change } \\
\text { from } \\
2014 / 15\end{array}$ \\
\hline Hauling Charges & \multicolumn{3}{|c|}{$\% / b o x$} & \multicolumn{5}{|c|}{$\$ /$ box } \\
\hline $0-30$ miles & \multicolumn{3}{|c|}{0.47} & $10 \%$ & \multicolumn{3}{|c|}{0.44} & $19 \%$ \\
\hline $31-50$ miles & \multicolumn{3}{|c|}{0.51} & $0 \%$ & \multicolumn{3}{|c|}{0.53} & $13 \%$ \\
\hline $51-80$ miles & \multicolumn{3}{|c|}{0.60} & $1 \%$ & \multicolumn{3}{|c|}{0.61} & $2 \%$ \\
\hline $81-100$ miles & \multicolumn{3}{|c|}{0.72} & $-3 \%$ & \multicolumn{3}{|c|}{0.70} & $-10 \%$ \\
\hline \multirow[t]{2}{*}{$100+$ miles } & \multicolumn{3}{|c|}{0.88} & $-12 \%$ & \multicolumn{3}{|c|}{0.64} & $-34 \%$ \\
\hline & & Averac & & $-1 \%$ & & Avera & & $-2 \%$ \\
\hline
\end{tabular}


Table 2. Estimated average of total harvesting charges for Florida citrus, 2015/16

\begin{tabular}{|c|c|c|}
\hline & Fresh Fruit & Processed Fruit \\
\hline & $\$ / b o x$ & $\$ / b o x$ \\
\hline Early and Mid-season Oranges & 3.10 & 3.14 \\
\hline Valencia Oranges & 3.25 & 3.24 \\
\hline Valencia Oranges (after May 15) & 3.61 & 3.55 \\
\hline Oranges Average ${ }^{2}$ & 3.17 & 3.22 \\
\hline Pink/Red Grapefruit & 2.59 & 2.72 \\
\hline White/March Grapefruit & 2.60 & 2.76 \\
\hline Grapefruit Average ${ }^{2}$ & 2.59 & 2.73 \\
\hline Temples/Tangelos & 4.83 & 4.14 \\
\hline Tangerines & 5.19 & 4.05 \\
\hline Specialty Citrus Average ${ }^{2}$ & 5.12 & 4.08 \\
\hline
\end{tabular}

